\title{
AVALIAÇÃO DA EFICIÊNCIA DOS PROCEDIMENTOS DE HIGIENIZAÇÃO E DESINFECÇÃO EM GALPÕES DE CRIAÇÃO SEMI-INTENSIVA DE AVES DE POSTURA DO CAMPUS FAEF - GARÇA-SP
}

\author{
EFFICACY EVALUATION OF HYGIENE AND DISINFECTION PROCEDURES IN \\ HENHOUSES OF SEMI-INTENSIVE LAYERS PRODUCTION AT CAMPUS FAEF- \\ GARÇA-SP, BRAZIL
}

Y. G. MARANGONI ${ }^{*}$, F. Z. ARAÚJO ${ }^{1}$, R. CANAL ${ }^{1}$, M. I. AMALFI ${ }^{1}$, J. ALEVATO ${ }^{1}$, M. Z. TRONCARELLI ${ }^{2}$, A. M. ANTONUCCI ${ }^{2}$

\begin{abstract}
RESUMO
O impacto econômico das doenças em avicultura é muito importante devido às mortalidades e redução da produção. O presente estudo apresenta dados parciais sobre a avaliação da carga microbiana ambiental em dois galpões de aves de postura da FAEF, antes e após a realização de procedimentos de higienização e desinfecção. Para a colheita das amostras com suabe estéril, foram determinados três momentos: 0) Imediatamente após a retirada do plantel; 1) Após a remoção da matéria orgânica, limpeza com água e sabão e pulverização com cloro a 13\%, e 2) Após aplicação de vassoura de fogo. Nos galpões 1 e 2 foram colhidas amostras em cinco pontos diferentes (A, B, C, D e E); quatro deles respeitando um padrão de 60 centímetros a partir do vértice das paredes, e um ponto no centro. No Galpão 2, os pontos D e E foram representados pelo ninho e comedouro de madeira, respectivamente. As amostras foram processadas no Laboratório de Diagnóstico Microbiológico Veterinário da FAEF. Cada suabe foi introduzido em tubo com 4,5 mL de solução salina, para obtenção de amostra "pura" e, a partir desta, procederam-se diluições seriadas a $10^{0}, 10^{-1}, 10^{-2}, 10^{-3} \mathrm{e} 10^{-4}$. Inóculos de 20 microlitros a partir de cada tubo foram semeados em placas com meio PCA e incubadas por 24 horas a $37^{\circ} \mathrm{C}$, para contagem das unidades formadoras de colônias (ufc). Verificou-se que as cargas microbianas iniciais foram consideravelmente reduzidas após os procedimentos de higienização e desinfecção. No entanto, nos pontos D e E do galpão 2, as cargas microbianas pós-desinfecção permaneceram elevadas, reforçando a dificuldade de eliminação de microorganismos a partir de materiais porosos. Os resultados indicam adequado manejo higiênico-sanitário adotado na granja de poedeiras do campus FAEF - Garça e reforçam a importância destas medidas para a prevenção da ocorrência de doenças infecciosas em aves.
\end{abstract}

PALAVRAS-CHAVE: BIOSSEGURIDADE. MICROBIOLOGIA. MANEJO SANITÁRIO. AVICULTURA.

AGRADECIMENTOS: FAEF - Garça-SP.

ÁREA TEMÁTICA: Doenças Infecciosas. 